DOI: https://doi.org/10.47405/mjssh.v6i3.687

\begin{tabular}{|c|c|}
\hline$x=$ & Malaysian Journal of Social Sciences and Humanities (MJSSH) \\
\hline $\begin{array}{l}\text { Malaysian Journal of } \\
\text { Socail cciences and }\end{array}$ & Volume 6, Issue 3, March 2021 \\
\hline (mu-ssh) & e-ISSN : 2504-8562 \\
\hline & $\begin{array}{l}\text { Journal home page: } \\
\text { www.msocialsciences.com }\end{array}$ \\
\hline
\end{tabular}

\title{
Personaliti, Iklim Sekolah, Kurikulum dan Sikap Akademik Pelajar di Institusi Tahfiz Negeri Sabah
}

\author{
Muhamad Suhaimi Taat', Roslee Talip, Musirin Mosin'1 \\ ${ }^{1}$ Fakulti Psikologi dan Pendidikan, Universiti Malaysia Sabah (UMS) \\ Correspondence: Muhamad Suhaimi Taat (suhaimi@ums.edu.my)
}

\begin{abstract}
Abstrak
Kajian ini bertujuan untuk mengkaji personaliti pelajar tahfiz, iklim sekolah, kurikulum dan sikap akademik murid tahfiz di Kota Kinabalu, Sabah. Kajian ini melibatkan seramai 81 orang murid tahap dua (tahun 4 - 6) daripada 3 buah sekolah rendah tahfiz swasta di sekitar Kota Kinabalu. Kajian kuantitatif ini menggunakan kaedah tinjauan keratan rentas dengan mengedarkan borang soal selidik kepada responden kajian. Analisis deskriptif menunjukkan variabel personaliti dan sikap pelajar menunjukkan tahap yang tinggi dengan skor min melebihi 3.80, manakala bagi variabel iklim sekolah, dapatannya adalah pada tahap sederhana ( $\mathrm{Min}=3.56, \mathrm{SP}=0.530$ ). Bagi variabel kurikulum pula, kebanyakan pelajar mempelajari mata pelajaran-mata pelajaran utama yang sama dipelajari di sekolahsekolah rendah bantuan penuh kerajaan di samping mata pelajaran al-Quran. Namun begitu, tiada seorang pun yang mempelajari mata pelajaran Pendidikan Komputer. Diharapkan kajian ini akan dapat memberikan maklumat berguna untuk penambahbaikan institusi tahfiz.
\end{abstract}

Kata kunci: tahfiz, iklim, kurikulum, sikap, akademik

\section{Personality, School Climate, Curriculum and Academic Attitude of Students in of Students in Sabah Tahfiz Institution Sabah Tahfiz Institution}

Abstract

This study aims to examine the personality of tahfiz students, school climate, curriculum, and academic attitudes of tahfiz students in Kota Kinabalu, Sabah. This study involved a total of 81 level two students (years 4 - 6) from 3 private tahfiz primary schools around Kota Kinabalu. This quantitative study uses cross-sectional survey methods by distributing questionnaires to the respondents. Descriptive analysis showed that the personality and attitude variables of students showed a high level with a mean score above 3.80, while for the school climate variable, the findings were at a moderate level (Mean $=3.56, \mathrm{SP}=0.530$ ). As for curriculum variable, most students learn the same main subjects learnt in government-aided primary schools, with addition to Quranic subjects. However, no one learnt Computer Education. It is hoped that this study will be able to provide useful information for the improvement of tahfiz institutions.

Keywords: tahfiz, environment, curriculum, attitude, academic 


\section{Pengenalan}

Institusi Tahfiz berkembang dengan pesatnya di Malaysia sejak sedekad ini. Kesedaran ibu bapa dan masyarakat berkaitan kepentingan pendidikan agama dan inspirasi untuk melahirkan seorang hafiz dalam satu keluarga telah menggalakkan pertumbuhan sekolah-sekolah tahfiz di seluruh negara termasuklah di negeri Sabah. Namun begitu kewujudan begitu banyak sekolah tahfiz telah mengundang pelbagai isu seperti hala tuju dan objektif, kualiti pengajaran dan pembelajaran (Nor Hisyam et al., 2007 ; Hamidah et al.,2017 ; Abdul Rahman dan Azmil, 2018), keseragaman sukatan pelajaran atau modul pembelajaran dan masalah kewangan dan masa depan para pelajar ini setelah tamat pengajian mereka nanti (Norlizah et al., 2015; Mohd Jamalil et al., 2017). Tujuan utama kajian ini dijalankan adalah untuk mengenal pasti faktor asas berkaitan hala tuju dan kurikulum kepada kelestarian institusi Tahfiz di negeri Sabah ini. Faktor-faktor tersebut adalah personaliti pelajar, iklim sekolah, kurikulum dan sikap akademik pelajar yang menjadi antara variabel utama ke arah kelestarian dan kecemerlangan institusi Tahfiz.

\section{Sorotan Literatur}

Falsafah Pendidikan di Malaysia bermatlamat melahirkan insan yang seimbang, harmonis dan berketerampilan. Sistem pendidikan negara kita juga memberikan kebebasan kepada para pelajar untuk memilih bidang-bidang tertentu yang mereka minati, antaranya bidang hafazan al-Quran. Institusi Tahfiz menjadi satu fenomena baharu dan berkembang dengan pesatnya di Malaysia sejak lebih satu dekad ini (Kamsaton et al., 2005). Kebimbangan ibu bapa terhadap pelbagai isu sosial yang melanda negara khususnya golongan remaja dan kesedaran masyarakat berkaitan kepentingan pendidikan agama dan inspirasi untuk melahirkan seorang individu yang lengkap (hafiz, agama dan akademik) dalam satu keluarga telah menggalakkan penubuhan sekolah-sekolah tahfiz kerajaan atau swasta di seluruh negara termasuklah di negeri Sabah. Namun begitu kewujudan sekolah-sekolah tahfiz seumpama cendawan yang tumbuh selepas hujan ini telah mengundang pelbagai isu dan fenomena. Antara isu yang sering diutarakan adalah hala tuju dan objektif sebenar penubuhan sekolah-sekolah tahfiz ini. Selain itu, kualiti pelaksanaan pengajaran dan pembelajaran yang dijalankan di sekolah-sekolah tahfiz serta kualiti pelajar-pelajar yang dihasilkan. Kajian berkaitan pembelajaran terarah kendiri pelajar tahfiz juga belum banyak yang dijalankan (Muhamad Suhaimi \& Mohd Yusof, 2014).

Kebanyakan sekolah tahfiz yang wujud khususnya di Sabah ini tidak mempunyai sukatan pelajaran atau modul pembelajaran yang seragam. Ini ditambah lagi dengan pelbagai masalah atau kekangan yang dihadapi seperti masalah kewangan bagi menampung perbelanjaan mengurus dan menyelenggarakan sekolah-sekolah tahfiz. Peristiwa kebakaran beberapa buah sekolah tahfiz yang menyayat hati juga telah membuka mata pelbagai pihak berkaitan isu jaminan keselamatan dan kesihatan serta kelengkapan prasarana di sekolah-sekolah tahfiz. Seperti yang telah dinyatakan tadi, kebanyakan sekolah-sekolah Tahfiz yang diwujudkan juga mengalami masalah dana untuk menampung operasi sekolah dan terpaksa meminta sumbangan awam bagi membiayai perbelanjaan mengurus dan penyelenggaraan sekolah masing-masing. Namun begitu, biarpun pelbagai masalah yang timbul, sekolah Tahfiz masih mendapat sambutan yang menggalakkan daripada kalangan ibu bapa. Justeru beberapa kajian telah dijalankan oleh beberapa pengkaji dalam negara untuk melihat dan mengkaji fenomena ini. Antaranya adalah kajian oleh Noor Hisyam et al.(2007) dan Hamidah et al.(2017) mendapat bahawa hala tuju dan matlamat sekolah tahfiz masih kabur. Tambahan pula Mohd Jamalil et al.(2017) menjelaskan bahawa peranan pentadbir, proses pengajaran dan pembelajaran dan strategi kecemerlangan di institusi pendidikan tahfiz yang cemerlang perlu diperhalusi. Hal ini penting untuk dijadikan garis panduan kepada institusi pendidikan tahfiz di Malaysia bagi memperkasakan kecemerlangan pelajar diploma tahfiz al-Quran. Sekolah-sekolah tahfiz juga didapati tidak mempunyai peraturan yang seragam dalam aspek pemilihan pelajar bagi kemasukan ke sekolah masing-masing (Norlizah et al., 2015; Noor Hisham \& Nasrun, 2017). Ketiadaan skim perjawatan yang seragam juga telah menjadi faktor kekangan di sekolah tahfiz (Azmil et al., 2016). Selain itu, kajian Abd Rahman et al. (2011) mendapati bahawa kebanyakan sekolah tahfiz ini mempunyai objektif, pendekatan dan pengurusan yang berbeza. Selain itu jangkaan dan komitmen guru dan pelajar juga adalah perlu untuk 
kecemerlangan akademik (Agatha dan Muhamad Suhaimi, 2016 ; Elver et al., 2017). Pengurusan kelas guru dan suasana pembelajaran yang kondusif juga amatlah penting bagi memastikan kualiti pengajaran (Gladys \& Muhamad Suhaimi, 2015 ; Jaggil \& Muhamad Suhaimi, 2018 ; Mazni et al., 2019).

\section{Objektif Kajian}

Untuk mengenal pasti personaliti, iklim sekolah, kurikulum dan sikap pelajar di sekolahsekolah tahfiz.

\section{Metod Kajian}

Kajian ini menggunakan reka bentuk bukan eksperimen iaitu dengan menggunakan pendekatan kuantitatif bagi mendapatkan data-data kajian. Set borang soal selidik tertutup digunakan sebagai instrumen kajian. Item-item soal selidik dibina sendiri oleh kumpulan penyelidik yang terdiri daripada mereka yang pakar dalam bidang kajian ini. Soal selidik ini telah menjalani proses kesahan dan kebolehpercayaan untuk memastikan item-item kajian boleh mengukur apa yang sepatutnya diukur. Kesemua item dikekalkan kerana memiliki nilai faktor muatan sekurang-kurangnya 0.40 dan kesemua variabel juga menunjukkan nilai kebolehpercayaan (Cronbach alpha) melebihi 0.60. Populasi kajian adalah murid-murid tahap 2 (tahun 4,5 \& 6) di tiga buah sekolah tahfiz di sekitar daerah Kota Kinabalu yang dianggarkan seramai 160 orang. Sampel kajian telah dipilih secara rawak mudah seramai 81 orang. Jumlah ini adalah mencukupi bagi melaksanakan analisis deskriptif mahupun inferens (Bartlett et. al, 2001). Data kuantitatif ini telah dianalisis secara deskriptif menggunakan perisian SPSS (frekuensi/peratus dan skor min/sisihan piawai).

\section{Hasil Kajian}

\section{Analisis Deskriptif Demografi Responden}

Berdasarkan Jadual 1, menunjukkan bahawa $50(63 \%)$ responden adalah berasal bandar dan seramai 30 $(37 \%)$ berasal dari luar bandar.

Jadual 1: Analisis Deskriptif Responden Berdasarkan Lokasi

\begin{tabular}{llcc}
\hline & & Kekerapan & Peratus \\
\hline \multirow{3}{*}{ Lokasi } & Bandar & 51 & 63.0 \\
& Luar bandar & 30 & 37.0 \\
& Total & 81 & 100.0 \\
\hline
\end{tabular}

Seterusnya, berdasarkan Jadual 2, didapati seramai 48 (59.3\%) responden adalah lelaki dan selebihnya iaitu $33(40.7 \%)$ adalah perempuan.

Jadual 2: Analisis Deskriptif Responden Berdasarkan Jantina

\begin{tabular}{|c|c|c|c|}
\hline & & Kekerapan & Peratus \\
\hline \multirow{3}{*}{ Jantina } & Lelaki & 48 & 59.3 \\
\hline & Perempuan & 33 & 40.7 \\
\hline & Total & 81 & 100.0 \\
\hline
\end{tabular}




\section{Analisis Deskriptifbagi Variabel Kajian}

Berdasarkan Jadual 3, dapatan menunjukkan bahawa secara umumnya murid-murid di institusi tahfiz memiliki personaliti yang baik serta positif. Antara item yang menunjukkan skor tertinggi adalah item 'Saya suka guru yang menegur kesalahan dengan baik' (4.38). Saya akan berdoa apabila saya menghadapi masalah (4.36), dan 'Saya akan meminta maaf apabila saya melakukan kesalahan' (4.26). Aspek-aspek positif ini menunjukkan bahawa responden memiliki nilai kendiri yang baik. Manakala antara item yang mendapat skor rendah adalah "Saya dapat mengawal emosi apabila marah'(3.15), Saya berpendapat diri saya sebagai seorang yang amat berharga (3.40), dan 'Saya suka berterus terang tentang sesuatu hal' (3.49). Daripada skor-skor yang agak rendah tersebut, menunjukkan bahawa responden masih lagi belum mempunyai emosi yang stabil dan kuat. Namun dapatan ini adalah dijangkakan kerana responden adalah murid-murid sekolah rendah yang rata-ratanya belum matang daripada aspek emosi dan perasaan.

Jadual 3 : Statistik Deskriptif Variabel Personaliti

\begin{tabular}{|c|c|c|c|c|c|}
\hline & $\mathbf{N}$ & Minimum & Maksimum & Mean & $\mathbf{S P}$ \\
\hline $\begin{array}{l}\text { Saya tidak suka dengan guru yang } \\
\text { mendenda/menghukum saya }\end{array}$ & 81 & 1 & 5 & 2.30 & 1.112 \\
\hline $\begin{array}{l}\text { Saya sanggup berbohong untuk } \\
\text { mengelakkan diri daripada dikenakan } \\
\text { hukuman }\end{array}$ & 81 & 1 & 5 & 1.68 & .946 \\
\hline $\begin{array}{l}\text { Saya mudah tersinggung apabila pendapat } \\
\text { saya ditolak }\end{array}$ & 81 & 1 & 5 & 3.02 & .987 \\
\hline $\begin{array}{l}\text { Saya akan berdoa apabila saya } \\
\text { menghadapi masalah }\end{array}$ & 81 & 1 & 5 & 4.36 & .841 \\
\hline $\begin{array}{l}\text { Saya dapat mengawal emosi apabila } \\
\text { marah }\end{array}$ & 81 & 1 & 5 & 3.15 & .963 \\
\hline $\begin{array}{l}\text { Saya berpendapat diri saya sebagai } \\
\text { seorang yang amat berharga }\end{array}$ & 81 & 1 & 5 & 3.40 & 1.176 \\
\hline $\begin{array}{l}\text { Saya bersedia mendengar pendapat orang } \\
\text { lain }\end{array}$ & 81 & 1 & 5 & 3.74 & .997 \\
\hline $\begin{array}{l}\text { Saya aktif menyertai aktiviti kokurikulum } \\
\text { di sekolah }\end{array}$ & 81 & 1 & 5 & 4.07 & 1.022 \\
\hline $\begin{array}{l}\text { Saya suka berterus terang tentang sesuatu } \\
\text { hal }\end{array}$ & 81 & 1 & 5 & 3.49 & .896 \\
\hline $\begin{array}{l}\text { Saya suka guru yang menegur kesalahan } \\
\text { dengan baik }\end{array}$ & 81 & 1 & 5 & 4.38 & 1.102 \\
\hline $\begin{array}{l}\text { Saya suka memberi pertolongan apabila } \\
\text { saya diperlukan }\end{array}$ & 81 & 2 & 5 & 4.10 & .784 \\
\hline Saya mudah mesra dengan orang lain & 81 & 1 & 5 & 3.77 & .898 \\
\hline
\end{tabular}


Saya akan meminta maaf apabila saya melakukan kesalahan

Saya akan menyelidik kebenaran sebelum mempercayai sesuatu yang orang cakap

Saya akan melakukan sesuatu dengan berhati-hati

Saya akan melakukan sesuatu kerja apabila saya meyakini boleh melakukannya dengan baik

Saya selalu berhati-hati apabila memberikan sesuatu pendapat
81

81

81

2

2

5

3.89

.866

1

5

3.85

.963

Berdasarkan Jadual 4, didapati secara umumnya skor min adalah pada tahap sederhana. Antara item yang menunjukkan skor min tertinggi adalah 'Kelas saya dilengkapi dengan kemudahan pengajaran dan pembelajaran' (4.00), 'Kawasan sekolah saya adalah ceria' (3.96), dan 'Kawasan sekolah saya adalah bersih' (3.65). Manakala antara item-item yang menunjukkan skor min rendah adalah 'Saya dan rakan banyak berbincang tentang pelajaran semasa di sekolah' (3.33), 'Rakan saya mengambil berat terhadap diri saya' (3.49), dan 'Saya mempercayai rakan-rakan saya di sekolah' (3.46). Daripada dapatan skor-skor min yang tinggi menunjukkan bahawa kemudahan dan keadaan fizikal kelas adalah pada tahap yang memuaskan, manakala hubungan antara responden dengan rakan-rakan mereka adalah pada tahap yang sederhana, khususnya berkaitan dengan perbincangan dengan rakan-rakan berkaitan pelajaran di sekolah.

Jadual 4 : Statistik Deskriptif Variabel Iklim Sekolah

\begin{tabular}{|c|c|c|c|c|c|}
\hline & $\mathbf{N}$ & Minimum & $\begin{array}{l}\text { Maksimu } \\
\text { m }\end{array}$ & Min & SP \\
\hline $\begin{array}{l}\text { Kelas saya dilengkapi dengan kemudahan } \\
\text { pengajaran dan pembelajaran }\end{array}$ & 81 & 2 & 5 & 4.00 & .880 \\
\hline $\begin{array}{l}\text { Keadaan kelas saya memberikan saya } \\
\text { motivasi untuk belajar }\end{array}$ & 81 & 1 & 5 & 3.60 & 1.033 \\
\hline $\begin{array}{l}\text { Bilangan pelajar dalam kelas saya adalah } \\
\text { ramai (sesak) }\end{array}$ & 81 & 1 & 5 & 3.73 & 1.204 \\
\hline Kawasan sekolah saya adalah bersih & 81 & 2 & 5 & 3.65 & .868 \\
\hline Kawasan sekolah saya adalah ceria & 81 & 2 & 5 & 3.96 & .872 \\
\hline $\begin{array}{l}\text { Guru kelas saya mengambil berat ke atas diri } \\
\text { saya }\end{array}$ & 81 & 1 & 5 & 3.84 & 1.012 \\
\hline $\begin{array}{l}\text { Guru kelas memberikan peluang untuk saya } \\
\text { berbincang mengenai sebarang masalah }\end{array}$ & 81 & 1 & 5 & 3.67 & 1.053 \\
\hline $\begin{array}{l}\text { Guru kelas saya selalu memberikan motivasi } \\
\text { kepada saya }\end{array}$ & 81 & 1 & 5 & 3.81 & 1.007 \\
\hline
\end{tabular}


Malaysian Journal of Social Sciences and Humanities (MJSSH), Volume 6, Issue 3, (page 80 - 90), 2021

DOI: https://doi.org/10.47405/mjssh.v6i3.687

Hubungan guru kelas dengan saya adalah mesra
81
2
5
3.74
.919

Saya mempercayai rakan-rakan saya di sekolah

$\begin{array}{lllll}81 & 1 & 5 & 3.46 & .903\end{array}$

Saya dan rakan banyak berbincang tentang pelajaran semasa di sekolah

$\begin{array}{lllll}81 & 1 & 5 & 3.33 & 1.061\end{array}$

Rakan saya mengambil berat terhadap diri saya

$\begin{array}{lllll}81 & 1 & 5 & 3.49 & 1.205\end{array}$

Bagi item-item bagi variabel sikap akademik pelajar pula, berdasarkan Jadual 5 menunjukkan bahawa hampir kesemua item menunjukkan skor min yang tinggi (>3.80). Keadaan ini menjelaskan bahawa sikap akademik para pelajar adalah amat positif dan mereka nampaknya dapat mengimbangi antara mata pelajaran Tahfiz/Agama dan mata pelajaran akademik. Antara item yang menunjukkan skor min yang tinggi adalah 'Saya ingin menghafal keseluruhan al-Quran (Hafiz) satu hari nanti' (4.52), 'Saya suka mempelajari al-Quran' (4.35), dan 'Saya memang berminat untuk belajar di sekolah ini' (4.30). Malahan mereka juga ingin melanjutkan pelajaran sama ada dalam bidang tahfiz/agama atau bidang selain itu selepas menamatkan pengajian di sekolah tahfiz tersebut.

Jadual 5 : Statistik Deskriptif Variabel Sikap Pelajar

\begin{tabular}{|c|c|c|c|c|c|}
\hline & $\mathbf{N}$ & Minimum & Maksimum & Min & $\mathbf{S P}$ \\
\hline $\begin{array}{l}\text { Jumlah mata pelajaran yang diajarkan tidak } \\
\text { membebankan saya }\end{array}$ & 81 & 1 & 5 & 3.59 & 1.081 \\
\hline $\begin{array}{l}\text { Sukatan pelajaran di sini adalah sesuai } \\
\text { dengan saya }\end{array}$ & 81 & 1 & 5 & 3.93 & .918 \\
\hline $\begin{array}{l}\text { Isi kandungan mata pelajaran al-Quran } \\
\text { adalah mudah untuk difahami }\end{array}$ & 81 & 2 & 5 & 4.12 & .910 \\
\hline $\begin{array}{l}\text { Kaedah atau teknik hafazan yang diajarkan } \\
\text { oleh Ustaz boleh saya ikuti dengan baik }\end{array}$ & 81 & 1 & 5 & 4.11 & .862 \\
\hline $\begin{array}{l}\text { Saya memang berminat untuk belajar di } \\
\text { sekolah ini }\end{array}$ & 81 & 1 & 5 & 4.30 & .872 \\
\hline Saya suka mempelajari al-Quran & 81 & 1 & 5 & 4.35 & .883 \\
\hline Saya suka mendalami ilmu al-Quran & 81 & 2 & 5 & 4.27 & .822 \\
\hline $\begin{array}{l}\text { Saya ingin menghafal keseluruhan al-Quran } \\
\text { (Hafiz) satu hari nanti }\end{array}$ & 81 & 1 & 5 & 4.52 & .823 \\
\hline $\begin{array}{l}\text { Mata pelajaran akademik (seperti Sains, } \\
\text { Matematik dan Bahasa Inggeris) tidak } \\
\text { penting bagi saya }\end{array}$ & 81 & 1 & 5 & 1.62 & .982 \\
\hline
\end{tabular}


Saya lebih menyukai mata pelajaran agama/al-Quran berbanding mata pelajaran akademik

81

81

Setelah tamat belajar di sekolah ini, saya akan meneruskan lagi pengajian dalam bidang agama

Setelah menghafal keseluruhan al-Quran (Hafiz), saya ingin melanjutkan pelajaran dalam bidang akademik lain (seperti kedoktoran, kejuruteraan, kesenian, ekonomi dan lain-lain) $\begin{array}{llll}81 & 1 & 5 & 3.95\end{array}$

Setelah item-item negatif dilakukan proses 'reverse coding', maka dapatan analisis deskriptif seperti di atas telah diperoleh. Dapatan menunjukkan bahawa secara keseluruhannya variabel Personaliti dan Sikap menunjukkan nilai skor min yang tinggi / baik / positif kerana melebihi nilai skor min 3.80. Manakala variabel Iklim Sekolah menunjukkan nilai skor min yang sederhana iaitu 3.56. Bagi variabel kurikulum pula, terdapat 25 mata pelajaran yang ditanya sama ada diajarkan atau tidak di sekolah (Diajarkan=1 markah, Tidak Diajarkan=0 markah), yang akan membawa total markah 24 sekiranya kesemua mata pelajaran tersebut diajarkan di sekolah. Mata pelajaran tersebut adalah Bahasa Melayu, Bahasa Inggeris, Bahasa Arab, Matematik, Sains, Pendidikan Islam, Pendidikan al-Quran, Pendidikan Komputer, Pendidikan Jasmani dan Kesihatan, Sejarah, SRU, Akhlak, Fikah, Hadis, Imlak, Sirah, Tajwid, Tauhid, Tafsir, Khat, Bahasa Cina, Ibadah, Tilawah al-Quran, Jawi, dan Akidah. Dapatan menunjukkan skor min untuk kurikulum adalah 15 iaitu pada tahap sederhana. Dapatan menunjukkan kesemua pelajar mengambil mata pelajaran Bahasa Melayu, Bahasa Inggeris, Bahasa Arab, Matematik, Sains, Pendidikan Islam, Pendidikan al-Quran dan Pendidikan Jasmani Kesihatan. Manakala, tiada pelajar yang mengambil mata pelajaran Pendidikan Komputer. Bagi mata pelajaran lain, sebahagian pelajar mempelajari dan sebahagian lagi tidak mempelajarinya.

Jadual 6 : Statistik Deskriptif Variabel-variabel Kajian

\begin{tabular}{cccccc}
\hline & N & Minimum & Maksimum & Min & SP \\
\hline Personaliti & 81 & 2.82 & 4.88 & 3.848 & .397 \\
Iklim Sekolah & 81 & 2.42 & 4.83 & 3.567 & .530 \\
Sikap & 81 & 2.17 & 5.00 & 3.869 & .532 \\
Kurikulum & 81 & 9.0 & 18.0 & 15.00 & 11.97 \\
\hline
\end{tabular}

\section{Perbincangan Kajian}

Berdasarkan analisis data secara deskriptif yang telah dijalankan, didapati bagi variabel kurikulum iaitu mata pelajaran-mata pelajaran yang diajar di sekolah-sekolah tahfiz yang terlibat dalam kajian ini adalah sama kecuali terdapat sebuah sekolah yang mengajar mata pelajaran Bahasa Cina. Ini merupakan sesuatu yang baik dan perlu dicontohi oleh sekolah-sekolah tahfiz lain kerana selain mempelajari Bahasa Melayu, Bahasa Inggeris dan Bahasa Arab, mereka juga perlu didedahkan dengan bahasa lain yang boleh membantu mereka pada masa hadapan. Maka secara umumnya, sekolahsekolah tahfiz yang dikaji masih relevan dengan kerana melaksanakan kurikulum yang sama agak komprehensif. Dapatan ini adalah selari dengan kajian oleh Zainora (2012), yang menunjukkan penilaian kurikulum qiraat iaitu kerelevenan kurikulum qiraat dan penilaian kendiri pensyarah adalah 
berada pada tahap tinggi. Namun begitu, kajian ini mendapati tiada sebuah sekolah pun yang mengajar mata pelajaran Pendidikan Komputer kepada murid-murid mereka. Sepatutnya di era Revolusi Industri 4 (IR4) ini, murid-murid perlu didedahkan dan dilengkapkan dengan ilmu pengetahuan berkaitan teknologi agar mereka tidak akan ketinggalan dalam era digital sekarang dan pada masa hadapan (Muhamad Suhaimi \& Agatha, 2020). Selain itu, teknik penyampaian guru juga boleh dipelbagaikan (Khalid et al., 2018). Beberapa kajian sebelum ini mendapati tidak terdapat keseragaman sukatan pelajaran atau modul pembelajaran dan masalah kewangan dan masa depan para pelajar ini setelah tamat pengajian mereka nanti (Norlizah et al., 2015; Mohd Jamalil et al., 2017). Selain itu, kajian Abd Rahman et al. (2011) mendapati bahawa kebanyakan sekolah tahfiz ini mempunyai objektif, pendekatan dan pengurusan yang berbeza. Bagi variabel iklim sekolah pula, didapati berada pada tahap sederhana. Dapatan ini menjelaskan bahawa murid-murid berpendapat suasana di sekolah mereka sama ada secara fizikal (infrastruktur) dan aspek interaksi masih boleh ditambah baik dan perlu diberikan perhatian. Antara perkara yang perlu ditambah baik adalah interaksi sesama murid-murid di dalam kelas dan suasana fizikal bilik darjah. Dapatan kajian ini adalah selari dengan kajian oleh Wan Zah et al., (2009) yang mendapati iklim pembelajaran di dalam bilik darjah berada pada tahap sederhana. Seterusnya, terdapat dapatan yang menunjukkan wujud perbezaan yang signifikan bagi persepsi terhadap aspek jangkaan guru, pengajaran guru dan layanan guru. Di samping itu juga, dapatan kajian mendapati pelajar pandai mempunyai perspektif lebih positif bagi ketiga-tiga aspek tersebut berbanding pelajar kelas lemah dan paling lemah. Selain itu, kajian oleh Mohd Faizul et al., (2016) menunjukkan tahap sederhana bagi tahap iklim sekolah dan kepuasan kerja guru di sekolah-sekolah menengah. Selain itu dalam kajian ini, bagi variabel sikap akademik murid berada pada tahap yang tinggi (baik). Ini bermakna, secara umumnya murid-murid yang belajar di sekolah tahfiz sememangnya mahu belajar di sekolah tersebut bagi mencapai cita-cita untuk bergelar seorang 'Hafiz' di samping ingin juga berjaya dalam bidang akademik. Kajian oleh Zaliza dan Zaitul Azma (2014) juga menunjukkan sebanyak 78\% daripada bilangan sampel kajian mempunyai sikap akademik yang positif. Seterusnya kajian oleh Ainun Rahmah et al., (2017), menunjukkan tahap sikap pelajar terhadap pembelajaran bahasa Melayu setelah diterapkan kemahiran abad ke-21 adalah berada pada tahap yang sangat tinggi. Sikap akademik yang positif ini ada hubungkaitnya dengan efikasi kendiri yang dimiliki oleh mereka (Muhamad Suhaimi \& Gladys, 2014).

\section{Kesimpulan}

Kajian ini dilaksanakan untuk mengenal pasti variabel personaliti, kurikulum, iklim sekolah dan sikap akademik murid-murid sekolah tahfiz. Objektif kajian telah dapat dicapai dan dijawab dengan menggunakan instrumen kajian yang sah dan dipercayai, serta analisis data yang digunakan juga adalah sesuai dengan jenis data dan soalan kajian yang ingin dijawab melalui analisis yang sesuai. Maka dapatlah dirumuskan bahawa murid-murid di sekolah Tahfiz mempunyai sikap akademik yang baik serta positif, dan sememangnya berminat dan mahu menjadi seorang penghafaz al-Quran, tanpa melupakan bidang akademik yang bagi mereka juga adalah penting bagi masa depan mereka. Namun begitu, murid-murid ini berpendapat bahawa aspek iklim sekolah perlu diberikan perhatian dan ditambah baik agar persekitaran pembelajaran yang lebih selesa, harmoni dan memberangsangkan dapat diwujudkan. Aspek motivasi juga harus diberikan perhatian agar mereka dapat belajar secara terarah kendiri (Muhamad Suhaimi et al., 2014). Diharapkan dengan kajian kecil yang merupakan satu tinjauan awal ini akan dapat memberikan input yang berguna untuk menjadi rujukan serta membuka jalan kepada penyelidikan seterusnya demi kelestarian institusi Tahfiz di negara kita dalam menghadapi pendidikan abad ke-21 pada masa kini.

\section{Rujukan}

Abdul Hafiz Abdullah, Hussin Salamon, Azmi Shah Suratman, Sulaiman Shakib Mohd Noor, Kamarul Azmi Jasmi \& Abdul Basit Samat. (2005). Sistem Pembelajaran dan Kaedah Hafazan al-Quran yang Efektif: Satu kajian di Kuala Lumpur dan Terengganu. UTM. 
Abdul Rahman Abd Ghani \& Azmil Hashim. (2018). Persepsi Guru Tahfiz al-Quran Terhadap Kemudahan Infrastruktur Institusi Tahfiz Persendirian di Negeri Selangor. Jurnal Kemanusiaan. 16(1), 1-6.

Abd Rahman Abd Ghani, Mohd Khafidz Soroni, Noorhafizah Mohd Haridi, Zainora Daud, Azmil Hashim \& Wan Sabariah WanYusoff. (2011). Pengurusan Institusi Tahfiz Persendirian di negeri Selangor.

Agatha Francis Umbit \& Muhamad Suhaimi Taat. (2016). The Effects of Expectations and Satisfaction Towards E-Learning Among Students. Journal of Modern Education Review, 6(9):603-611.

Ainun Rahmah Iberahim, Zamri Mahamod, \& Wan Muna Ruzanna Wan Mohammad. (2017). Pembelajaran abad ke-21 dan pengaruhnya terhadap sikap, motivasi dan pencapaian Bahasa Melayu pelajar sekolah menengah. Jurnal Pendidikan Bahasa Melayu ;Malay Language Education (MyLEJ), 7 (2). 77-88.

Azmil Hazhim \& Misnan Jemali. (2016). Kajian Mengenai Hubungan antara Teknik Pembelajaran Tahfiz dan Pencapaian Hafazan Al-Quran Para Pelajar. Jurnal Perspektif, 6(2), 15-25.

Azmil Hashim, Ab. Halim Tamuri. (2012). Persepsi Pelajar Terhadap Kaedah Pembelajaran Tahfiz alQuran di Malaysia. Journal of Islamic and Arabic Education, 4(2), 1-10.

Azmil Hashim, Mohd Marzuki Abdul Rahim, Wahyu Hidayat Abdullah. (2016). Role of Employers in Empowering Lecturers in Tahfiz Institutions of Malaysia. GJAT. 6(1).

Bartlett, II, J.E., Kotrlik, J.E. and Higgins, C.C. (2001). Organizational research: Determining appropriate sample size in survey research. Information Technology, Learning, and Performnace Journal. 19(1), 43-50.

Elver Fazly Charlie, Fiffy Hanisdah Saikim \& Muhamad Suhaimi Taat. (2017). Students' Interpretation and Commitment of Conservation Contents Based On School Context. Transaction on Science and Technology, 4(2): 157-165.

Gladys De Rozario \& Muhamad Suhaimi Taat. (2015). The Influence of Learning Environment And Academic Self-Efficacy Towards Mathematics Achievement In Masterskill Global College, Malaysia. International Journal of Arts and Commerce, 1: 43-53.

Hair, J.F., Black, W.C., Babin, B.J. and Anderson, R.E. (2010), Multivariate Data Analysis, 7th ed., Prentice Hall, Englewood Cliffs, NJ.

Hamidah Bani, Maheran Katan, Abd Halim Mohd Noor, Muhammad Mukhlis Abdul Fatah. (2014). Applying Stakeholder Approach in Developing Accountability Indicators for Tahfiz Centers. Proceedings of International Conference on Accounting Research and Education.

Hamidah Bani, Mohd Yassir Jaafar, Maheran Katan, Abd Halim Mohd Noor . (2017). An Overview of Governance and Accountability of Tahfiz Institutions in Malaysia: Religious Councils Perspective. SHS Web of Conferences 36.

Idris Jusoh. (2006). Satu pemikiran praktis dalam merealisasikan konsep Ulul Albab. Kertas Kerja Seminar Ulul Albab. Anjuran Bersama Kerajaan Negeri Terengganu dan Terengganu Development Institute. Kuala Terengganu.

Jaggil Apak \& Muhamad Suhaimi Taat. (2018). Pengaruh Kesediaan Guru Terhadap Pengurusan Bilik Darjah Abad Ke-21. Malaysian Journal of Social Sciences and Humanities, 3(4): 6-22.

Kamsaton Simon et al. (2005). Kepentingan Pengajian Tahfizal-Quran Terhadap Masyarakat Pada Masa Kini. Pusat Pengajian Islam dan Pembangunan Sosial (PPIPS). Skudai, Malaysia: UTM.

Khalid Abdulbaki, Muhamad Suhaimi, Asmaa Alsaqqaf, Wafa Jawad. (2018). The Use of the Discussion Method at University: Enhancement of Teaching and Learning. International Journal of Higher Education, 7(6): 118-128.

Mariam Abd. Majid, Sahlawati Abu Bakar, Zetty Norzuliana Mohd Rashed, Suriani Sudi, Wan Ramizah Hasan, Muhammad Yusuf Marlon Abdullah.(2015). Kaedah Pengajaran Guru Tilawah al-Quran: Kajian Kes di Maahad Integrasi Tahfiz Sains dan Teknilogi Negeri Selangor.

Mazni Muhammad, Roslee Talip, Muhammad Suhaimi Taat. (2019). Pengaruh Kualiti Pengajaran dan Pembelajaran Terhadap Kepuasan Belajar Pelajar Kolej-Kolej Swasta di Sabah. Jurnal Ilmi, 9: 102-119.

Mohd Faizul Mohd Noor, Mohd Saifulkhair Omar, Fauzi Hussin. 2016. Hubungan Iklim Sekolah Dan Stres Guru Sekolah Menengah Di Daerah Kuala Nerus, Terengganu. Proceeding of ICECRS, 
International Seminar on Generating Knowledge Through Research, UUM-UMSIDA, 25-27 October, Universiti Utara Malaysia, Malaysia.

Mohd Jamalil Ismail, Sabri Mohamad, Tengku Intan Zarina Tengku Puji, Nor Hafizi Yusof. (2017). Strategi Kecemerlangan Institusi Pendidikan Tahfiz al-Quran di Malaysia: Satu Tinjauan Literatur. Jurnal Islam dan Masyarakat Kontemporari, 15 (Julai).

Muhamad Suhaimi Taat \& Mohd Yusof Abdullah. (2014). The Influence of Attachment Styles on Students's Self Directed Learning. International Interdisciplinary Journal of Scientific Research, 1: $1-5$.

Muhamad Suhaimi Taat, Mohd Yusof Abdullah \& Roslee Talip. (2014). Motivasi Sebagai 'Mediator' antara Proses Pengajaran Dan Bimbingan Guru Dengan Pembelajaran Terarah Kendiri (PTK) Pelajar: Satu Kajian Menggunakan Model SEM/AMOS. Sains Humanika (UTM), 1: 127-132.

Muhamad Suhaimi Taat \& Agatha Francis. (2020). Factors Influencing the Students' Acceptance Of E-Learning at Teacher Education Institute: An Exploratory Study in Malaysia. International Journal of Higher Education, 9(1): 133-141.

Muhamad Suhaimi Taat, Gladys De Rozario. (2014). The Influence of Academic Attitude and SelfEfficacy Towards Students Achievement in Private Higher Learning Institution, Malaysia. International Journal of Arts and Commerce, 1: 41-50.

Nordin, Aziz and Lin, Hui Ling (2011) Hubungan sikap terhadap mata pelajaran sains dengan penguasaan konsep asas sains pelajar tingkatan dua. Journal of Science \& Mathematics Education, 4 (2), 89-101.

Noor Hisham Md Nawi \& Nasrun Hakim Salleh. (2017). Pembinaan Model Pengajian Tahfiz di Malaysia. The Online Journal of Islamic Education, 5(1), 1-11.

Noor Hisham Md Nawi, Nur Azuki Yusuff, Mohd Binyamin Che Yaacob, Nasrul Hakim Salleh. (2007). Matlamat dan Halatuju Sistem Pengajian Tahfiz di Kelantan: Satu Pengamatan Awal.

Norlizah Che Hassan, Fathiyah Mohd Fakhruddin, Ahmad Fauzi Mohd Ayub, Lukman Abd Mutalib, Wan Marzuki Wan Jaafar. (2015). International E-Journal of Advances in Education, 1(3), 234 244.

Nur Ahid. (2006). Konsep Dan Teori Kurikulum Dalam Dunia Pendidikan. ISLAMICA. 1(1), September, 12-29.

Ornstein, A., \& Hunkins, F. (2009). Curriculum Design. In Curriculum: Foundations, Principles and Issues (5th Ed.). Boston, MA: Pearson/Allyn and Bacon.

Ridza B.H, Jalil R.A, Sipan, I, Y. Nukman. (2017). Critical Success Factor (CSF) Service Delivery for Tahfiz Institution Teaching and Learning Environment. Proceedings of The 3rd International Conference on Construction and Building Engineering.

Rohaizan, B., Zulkifli, A., \& Abdul Hakim, A. (2014). Showcasing an Alternative Educational Systems Using the Philosophy of Ulul Albab. Swiss Journal of Research in Business and Social Sciences. 1(1), 1-10.

Sedek Ariffin, Mustaffa Abdullah, \& Ishak Sulaiman. (2013). Effective Techniques of Memorizing the Quran: A study at Madrasah ta hfiz Al-Quran, Terengganu, Malaysia. Middle-East Journal of Scientific Research.13(1), 45-48.

Wan Ezielia binti Wan Aziz. (2014). Pelaksanaan Pengurusan Kurikulum Dalam Kalangan GuruGuru Sekolah Menengah Kluster Daerah Johor Bahru. Tesis Sarjana. UTM

Wan Zah Wan Ali, Sharifah Md. Nor, Siti Suria Salim, Othman Mohamed, Kamariah Abu Bakar, Arshad Abd. Samad, Ramlah Hamzah, Rohani Ahmad Tarmizi, \& Rasid Jamian. Persepsi Pelajar Berisiko Terhadap Iklim Pembelajaran (At-Risk Students' Perception Toward Learning Climate). Jurnal Pendidikan Malaysia. 34 (1), 17-36.

Wang, M.T. \& Degol, J. (2016). Climate: A Review of the Construct, Measurement, and Impact on Student Outcomes. Educational Psychology Review. 28(2), 315-352

Zainora Daud. (2012). Kaedah pengajaran dan pembelajaran pengajian Qiraat di Jabatan Al-Quran dan Al-Qiraat, KUIS: satu tinjauan awal.

Zaliza Mohamad Nasir \& Zaitul Azma Zainon Hamzah (2014) Sikap Dan Motivasi Pelajar Terhadap Pembelajaran Bahasa Melayu. Procedia- Social and Behavioral Sciences. 134(15), 408-415.

Zetty Nerzuliana Rashed, Mariam Abd. Majid, Sahlawati Abu Bakar, Suriani Sudi, Wan Ramizah Hasan, Muhammad Yusuf Marlon B. Abdullah. (2015). Amalan Pengajaran Guru Tilawah al- 
Malaysian Journal of Social Sciences and Humanities (MJSSH), Volume 6, Issue 3, (page 80 - 90), 2021 DOI: https://doi.org/10.47405/mjssh.v6i3.687

Quran: Kajian Kes di Maahad Tahfiz Sains Negeri Selangor. Tinta Artikulasi Membina Ummah.1(1), 77-86. 